\title{
KOLABORASI DALAM PRAKTIK LAPANGAN - MENGAJAR GEOGRAFI LANJUT (PL-MGL) BERBASIS LESSON STUDY
}

\author{
Nofrion \\ Universitas Negeri Padang \\ Email: dion_geografi@yahoo.com
}

\begin{abstract}
Abstrak
Artikel ini ditulis untuk menjelaskan hasil penerapan Kolaborasi Berbasis Lesson Study dalam Praktik Lapangan Mengajar Geografi Lanjut (PL-MGL) bagi mahasiswa Program Studi Magister Pendidikan Geografi, Universitas Negeri Padang. Melalui kolaborasi berbasis Lesson Study dengan melaksanakan tiga pilar utamanya yaitu "Plan, Do dan See" diharapkan dapat meningkatkan kompetensi mahasiswa sebagai calon dosen profesional. Penelitian ini menggunakan metode deskriptif yang melibatkan empat orang mahasiswa Program Magister Pendidikan Geografi, FIS, UNP dan satu kelas mahasiswa S1 Pendidikan Geografi pada mata kuliah Geografi Sosial. Satu orang mahasiswa bertindak sebagai dosen model dan tiga orang lainnya sebagai observer pembelajaran. Data yang dikumpulkan adalah data kompetensi dosen dalam pembelajaran (capaian kinerja dosen) yang dikumpulkan dengan lembar observasi pembelajaran serta data pelaksanaan pembelajaran sebagai bahan refleksi yang dikumpulkan dengan lembar refleksi pembelajaran "three ways conference". Dosen model melaksanakan pembelajaran (open class) sebanyak empat kali pertemuan yang diawali dengan kegiatan "plan" dan diakhiri dengan kegiatan "see" yang dihadiri oleh tiga orang observer dan satu dosen penilai dan pembimbing. Hasil penelitian menunjukkan bahwa capaian kinerja dosen model dalam pembelajaran meningkat dari pertemuan 1 sampai ke pertemuan 4 serta mulai pertemuan kedua, dosen model sudah berhasil melewati batas minimal nilai kelulusan yaitu 70. Ditinjau dari kolaborasi peserta dalam kegiatan juga sangat baik. Hal ini terlihat dari kesungguhan peserta mengikuti semua tahap-tahap pembelajaran serta kontribusi mereka dalam kegiatan refleksi yang ditulis di lembar refleksi pembelajaran dan dibahas dengan teknik "three ways conference". Mahasiswa PL-MGL berpendapat bahwa kegiatan seperti ini sangat positif bagi mereka. Walaupun membutuhkan waktu yang lebih banyak dan energi yang lebih besar, namun mereka mendapatkan pelajaran yang sangat bernilai. Hal ini juga diapresiasi oleh ketua Program Studi Magister pendidikan Geografi sebagai suatu langkah positif dalam mengembangkan kompetensi calon dosen secara kolaboratif sehingga terwujud komunitas belajar yang efektif.
\end{abstract}

Kata Kunci : PL-MGL, Kolaborasi, Lesson Study

\section{A. Pendahuluan}

Sebagai pendidik profesional, seorang dosen harus memiliki empat kompetensi utama yaitu; 1) kompetensi pedagogik, 2) kompetensi profesional, 3) kepribadian dan 4) kompetensi sosial (UU No. 14 tahun 2005 tentang Guru dan Dosen). Hal ini juga diperkuat dengan Buku Pedoman Sertifikasi Pendidik untuk Dosen (Serdos) Terintegrasi yang dikeluarkan oleh Direktorat Jenderal Pendidikan Tinggi tahun 2015. Dalam buku ini dijelaskan bahwa kompetensi pedagogik adalah kemampuan pemahaman terhadap peserta didik, perancangan dan pelaksanaan pembelajaran, evaluasi hasil belajar dan pengembangan peserta didik untuk mengaktualisasikan 
potensi yang dimilikinya. Sedangkan kompetensi profesional adalah penguasaan materi pembelajaran secara luas dan mendalam serta penguasaan terhadap struktur dan metodologi keilmuan. Lalu, kompetensi sosial adalah kemampuan guru untuk berkomunikasi dan bergaul secara efektif dengan berbagai pihak. Terakhir, kompetensi kepribadian yaitu kemampuan personal yang mencerminkan kepribadian yang mantap, stabil, dewasa, arif dan berwibawa, menjadi teladan serta berakhlak mulia.

Untuk mengembangkan kompetensi tersebut Program Studi Magister Pendidikan Geografi, FIS, UNP mulai semester Januari - Juni 2017, melakukan pengembangan kurikulum dengan memasukkan mata kuliah Praktik Lapangan - Mengajar Geografi Lanjut atau PL-MGL dengan bobot 1 sks. Setiap mahasiswa wajib mengambil mata kuliah ini dan dinyatakan lulus jika mampu mendapatkan nilai akumulasi minimal 70 dari dosen pembimbing. PL-MGL bertujuan untuk memberikan pengalaman lapangan kependidikan yang komprehensif kepada mahasiswa sebagai calon pendidik/dosen nantinya. Melalui PL-MGL diharapkan mahasiswa dapat belajar dari pengalaman langsung praktik mengajar di kampus serta tugas-tugas pendidik lainnya. Dengan pengalaman tersebut, mahasiswa mendapatkan gambaran utuh tentang tugas dan fungsi sebagai calon pendidik/dosen di perguruan tinggi. Dalam kegiatan PL-MGL perdana semester ini, penulis mendapat kesempatan untuk membimbing empat orang mahasiswa magister yaitu Anisa Yudita, Dewilna Helmi, Belia Laksmi Masril dan Isni Mulyani. Dilihat dari latar belakang S1 mereka, satu orang lulusan UPI Bandung, satu orang lulusan STKIP PGRI Palembang dan dua orang lulusan Pendidikan Geografi UNP.

Keempat mahasiswa bimbingan penulis memiliki potensi dan keunggulan masingmasing. Namun, disisi lain juga memiliki beberapa kekurangan. Untuk menutupi kekurangan mereka dan menguatkan kelebihan yang mereka miliki maka penulis menciptakan suatu kondisi dimana mereka bisa saling berkolaborasi. Penulis menyebutnya dengan Kolaborasi berbasis Lesson Study/KBLS. Dasarnya adalah bahwa pengembangan kompetensi pendidik tidak bisa dilakukan sendiri namun membutuhkan dukungan, sinergi dan kolaborasi dengan orang lain. Moore (2005) mengatakan bahwa "effectives teachers must be engage in quality planning and preparation.... and exhibit profesional behavior". Intinya, guru yang efektif adalah guru yang terlibat dalam perencanaan dan persiapan belajar serta menunjukkan perilaku yang profesional. Dalam konteks PL-MGL ini, penulis menerapkan prinsip-prinsip kolaborasi dalam setiap proses dan kegiatan mulai tahap perencanaan (plan), pelaksanaan (do) dan refleksi (see).

Berbagai penelitian telah membuktikan bahwa penerapan pembelajaran kolaboratif mampu meningkatkan pencapaian peserta didik dalam banyak hal. Diantaranya mampu meningkatkan kemampuan berfikir dan mengolah informasi dibanding dengan belajar secara sendiri (Johnson R. T \& Johnson D, 1986). Lalu, mampu mendorong terciptanya akuntabilitas individu (Laal, Geranpaye \& Daemi (2013). Kemudian, Laal (2013) juga membuktikan bahwa pembelajaran kolaboratif mampu menciptakan saling ketergantungan yang positif diantara sesama siswa. Ghokale (1995) membuktikan bahwa nilai siswa yang belajar secara kolaboratif memiliki kemampuan berfikir tinggi yang lebih baik dibanding dengan siswa yang belajar sendiri. Kondisi ini sesuai dengan pendapat Vygotsky (1978) yang menyatakan siswa mampu menunjukkan performa kinerja berfikir tingkat tinggi jika belajar secara kolaborasi. 
Selanjutnya, dengan penerapan prinsip-prinsip kolaborasi dalam PL-MGL ini juga sesuai dengan pendapat Kemp, dkk dalam bukunya "Designing Effective Instruction" (1994) yang menjelaskan bahwa ada empat pihak yang harus terlibat dalam perencanaan, pengembangan, penerapan dan evaluasi pembelajaran, yaitu;

1. Perancang pembelajaran (instructional designer)

2. Pengajar (instructor)

3. Ahli materi pelajaran (subject-matter expert)

4. Penilai (evaluator)

Uraian di atas semakin mempertegas bahwa untuk hasil terbaik dalam pembelajaran guru tidak bisa bekerja sendiri. Harus ada kolaborasi. Dengan berkumpulnya berbagai ahli dalam merancang pembelajaran maka akan lahir rancangan pembelajaran yang lebih baik.

Dasar berikutnya adalah praktik lesson study. Lesson Study (jugyokenyu) sebagai suatu proses sistematis yang digunakan oleh guru-guru jepang untuk menguji keefektifan pengajarannya dalam rangka meningkatkan hasil pembelajaran telah terbukti. Proses sistematis yang dimaksud adalah kerja guru-guru secara kolaboratif untuk mengembangkan rencana dan perangkat pembelajaran, melakukan observasi, refleksi, dan revisi rencana pembelajaran secara bersiklus dan terus menerus. Lewis (2002) berpendapat bahwa ide yang terkandung di dalam Lesson Study sebenarnya singkat dan sederhana, yakni jika seorang guru ingin meningkatkan pembelajaran, salah satu cara yang paling jelas adalah melakukan kolaborasi dengan guru lain untuk merancang, mengamati dan melakukan refleksi terhadap pembelajaran yang dilakukan. Lesson Study adalah suatu metode analisis kasus pada praktik pembelajaran, ditujukan untuk membantu pengembangan profesionalitas guru dan membuka kesempatan bagi mereka untuk saling belajar berdasarkan praktik-praktik nyata di tingkat kelas.

Menurut Sato (2012), Lesson Study memiliki tiga pilar utama yaitu, 1) Plan (perencanaan). Pada bagian ini seorang atau sekelompok guru membuat perencanaan pembelajaran berdasarkan pembelajaran sebelumnya, 2) Do (Pelaksanaan), satu guru melaksanakan pembelajaran (guru model) berdasarkan perencanaan yang telah dibuat dan teman sejawatnya mengamati pembelajaran (observer), dan 3) See (refleksi) yaitu mereka merefleksikan pembelajaran yang diamati bersama-sama. Lesson Study merupakan pendekatan yang efektif dalam mengembangkan pembelajaran yang berkesinambungan dan bersifat kolaboratif. Penerapan prinsip-prinsip kolaborasi dan Lesson Study dalam PL-MGL ini dalam upaya membangun komunitas belajar. Sato (2012) menjelaskan bahwa komunitas belajar bertujuan untuk meningkatkan kualitas pembelajaran, serta pencapaian simultan antara kualitas dan kesetaraan. Lebih lanjut dijelaskan bahwa dengan terciptanya komunitas belajar setiap guru akan mampu bertransformasi menjadi ahli pembelajaran (Sato, 2012).

\section{B. Metode}

Penelitian ini menggunakan metode deskriptif. Penelitian deskriptif memusatkan perhatian kepada pemecahan masalah-masalah aktual sebagaimana yang ada pada saat penelitian dan berfungsi untuk pemecahan masalah praktis. Dilihat dari topik penelitian maka jenis penelitian ini termasuk deskriptif survei pendidikan. Data dikumpulkan dengan lembar observasi pembelajaran dan lembar refleksi "three ways conference" 
yang telah dimodifikasi sesuai tujuan penelitian. Analisis data menggunakan statistic deskriptif. Populasi penelitian ini adalah mahasiswa PL-MGL yang berada dalam bimbingan penulis sebanyak empat orang. Pemilihan guru model dilakukan dengan cara acak sebanyak satu orang. Dengan demikian, dalam setiap pembelajaran terdiri dari satu guru model, tiga orang observer dan satu dosen penilai. Hasil yang diharapkan dalam penelitian ini adalah meningkatkan kemampuan dosen model dalam melaksanakan pembelajaran serta terwujudnya komunitas belajar yang efektif diantara mereka.

Tabel 1. Aspek dan Teknik Penilaian/Observasi

\begin{tabular}{|l|l|l|l|l|}
\hline 1 & \multicolumn{1}{|c|}{ Tahapan } & \multicolumn{1}{|c|}{$\begin{array}{c}\text { Aspek yang } \\
\text { dinilai }\end{array}$} & Alat ukur & \multicolumn{1}{|c|}{ Keterangan } \\
\hline 2 & $\begin{array}{l}\text { Perencanaan/ } \\
\text { Plan }\end{array}$ & $\begin{array}{l}\text { Perangkat } \\
\text { Perkuliahan } \\
\text { (SAP/RPP dan } \\
\text { Bahan Ajar) }\end{array}$ & $\begin{array}{l}\text { Lembar } \\
\text { check list }\end{array}$ & $\begin{array}{l}\text { Penilaian perangkat tan } \\
\text { diselesaikan sebelum pelaksanaan } \\
\text { pembelajaran karena dalam jadwal } \\
\text { PL-MGL ada waktu khusus untuk } \\
\text { menyelesaikan perangkat. } \\
\text { Mahasiswa boleh tampil setelah } \\
\text { perangkat selesai dengan benar. }\end{array}$ \\
\hline 3 & $\begin{array}{l}\text { Pelaksanaan/ } \\
\text { Do }\end{array}$ & $\begin{array}{l}\text { Model, } \\
\text { Metode, Media }\end{array}$ & $\begin{array}{l}\text { Lembar } \\
\text { Observasi } \\
\text { Pembelaja } \\
\text { ran }\end{array}$ & $\begin{array}{l}\text { Diamati dan dinilai oleh dosen } \\
\text { pembimbing }\end{array}$ \\
\hline 4 & Penilaian/See & $\begin{array}{l}\text { Proses } \\
\text { pembelajaran }\end{array}$ & $\begin{array}{l}\text { Lembar } \\
\text { refleksi } \\
\text { "three } \\
\text { ways } \\
\text { conference } \\
\text { " }\end{array}$ & $\begin{array}{l}\text { Diamati oleh tiga orang observer } \\
\text { pembelajaran }\end{array}$ \\
\hline
\end{tabular}

\section{Hasil dan Pembahasan}

Berdasarkan pedoman pelaksanaan PL-MGL yang dikeluarkan oleh Ketua Program Studi Magister Pendidikan Geografi, FIS, UNP maka pelaksanaan PL-MGL ini dilaksanakan empat minggu perkuliahan. Langkah-langkah awal penelitian adalah:

1. Menyamakan persepsi antara peserta PL-MGL dengan Dosen Pembimbing. Hasilnya, peserta sangat tertarik dengan pola PL-MGL yang dirancang yaitu Kolaboratif Berbasis Lesson Study/KBLS).

2. Menyepakati jadwal "Plan". Peserta menyepakati bahwa jadwal "Plan" adalah satu hari sebelum "do/open class".

3. Menyepakati kelas praktik PL-MGL/Open Class. Kelas yang disepakati adalah kelas Mata Kuliah Geografi Sosial dengan jadwal hari Kamis pukul 13.30 15:00 di ruang 14304 Gedung SMK Labor UNP Lantai 3.

4. Menyepakati jadwal "plan' dan "open class". Hasil kesepakatan adalah;

a. Pertemuan 1, Kamis tanggal 27 April 2017

b. Pertemuan 2, Kamis tanggal 4 Mei 2017

c. Pertemuan 3, Rabu tanggal 10 Mei 2017

d. Pertemuan 4, Jumat tanggal 12 Mei 2017

Kegiatan "Plan" direncanakan satu hari sebelum "open class". 
5. Menyepakati jadwal "see" atau refleksi. Hasil kesepakatan bersama adalah bahwa kegiatan refleksi dilaksanakan setelah "open class".

6. Memilih dosen model. Pemilihan dilakukan secara acak. Yang terpilih sebagai Dosen Model adalah Anisa Yudita. Dengan demikian observer pembelajaran adalah Belia, Dewilna dan Isni. Sedangkan Dosen Pembimbing bertindak sebagai observer dan penilai.

Profil singkat peserta PL-MGL dengan teknik Kolaborasi Belajar Berbasis Lesson Study adalah;

Tabel 2. Profil Peserta PL-MGL Semester Januari - Juni 2017

\begin{tabular}{|c|l|l|l|}
\hline No & \multicolumn{1}{|c|}{ Nama } & \multicolumn{1}{c|}{ Asal S1 } & \multicolumn{1}{c|}{ Peranan } \\
\hline 1 & Anisa Yudita & UPI Bandung & Dosen Model \\
\hline 2 & Belia Laksmi Masril & UNP & Observer 1 \\
\hline 3 & Isni Mulyani & $\begin{array}{l}\text { STKIP PGRI } \\
\text { Palembang }\end{array}$ & Observer 2 \\
\hline 4 & Dewilna Helmi & UNP & Observer 3 \\
\hline
\end{tabular}

Hasil penelitian ini difokuskan pada dua aspek yaitu; 1) perkembangan kompetensi pendidik guru model yang dilihat dari nilai pada lembar observasi pembelajaran yang diberikan oleh dosen pembimbing dan 2) rekap refleksi pembelajaran dengan teknik 'three way conference" yang diberikan oleh observer.

Sehubungan dengan tujuan PL-MGL yaitu mengembangkan kompetensi mahasiswa S2 untuk menjadi calon Dosen maka perlu diberikan nilai terhadap kinerja yang bersangkutan dalam proses pembelajaran. Dalam artikel ini, guru model yang terpilih adalah Annisa Yudita yang melaksanakan pembelajaran pada Mata Kuliah Geografi Sosial. Berikut perkembangan kompetensi Annisa Yudita dalam empat kali pertemuan/pembelajaran.

\section{Analisis Pertemuan (Open Class) 1}

Pertemuan dilaksanakan pada hari kamis, tanggal 27 April 2017 pada mata kuliah Geografi Sosial. Bertindak sebagai dosen model adalah Anisa Yudita. Observer pembelajaran tiga orang dan satu dosen penilai. Sebelumnya, kegiatan "Plan 1" dilaksanakan pada hari Rabu tanggal 26 April 2017 di ruang Ketua Program Studi Pendidikan Geografi, FIS UNP. Kinerja pelaksanaan pembelajaran dosen model pada pertemuan pertama adalah;

Tabel 3. Capaian Kinerja Pertemuan 1

\begin{tabular}{|c|l|c|l|}
\hline No & \multicolumn{1}{|c|}{ Kegiatan } & Nilai & \multicolumn{1}{|c|}{ Keterangan } \\
\hline 1 & Pendahuluan & 66,66 & Belum Lulus \\
\hline 2 & Kegiatan inti & 60 & Belum Lulus \\
\hline 3 & Penutup & 66,66 & Belum Lulus \\
\hline
\end{tabular}

Sumber : Pengolahan Data Penelitian 2017

Dari tabel di atas terlihat bahwa kinerja dosen model pada semua tahap pembelajaran belum tuntas. Kinerja terendah justru berada pada kegiatan ini. Salah satu faktor penyebab rendahnya kinerja dosen model karena masih dalam proses penyesuaian dan 
pengalaman pertama di kelas tersebut. Untuk mendapatkan gambaran lebih lanjut, dilakukan analisis data refleksi pembelajaran dengan teknik "the way conference". Hasilnya sebagai berikut;

Tabel 4. Refleksi Pembelajaran Pertemuan 1

\begin{tabular}{|c|c|c|c|c|}
\hline No & Observer & Tiga Kekuatan & Dua Kelemahan & Satu Solusi \\
\hline 1 & BLM & $\begin{array}{l}\text { 1. Orientasi bagus } \\
\text { 2. Materi bagus } \\
\text { 3. Komunikasi bagus }\end{array}$ & $\begin{array}{l}\text { 1. Penggunaan } \\
\text { whiteboard } \\
\text { 2. Referensi }\end{array}$ & $\begin{array}{ll}\text { Cari } & \text { referensi } \\
\text { terbaru } & \end{array}$ \\
\hline 2 & IM & $\begin{array}{l}\text { 1. Komunikasi bagus } \\
\text { 2. Penyajian materi bagus } \\
\text { 3. PPT menarik }\end{array}$ & $\begin{array}{l}\text { 1. Pengelolaan kelas } \\
\text { kurang } \\
\text { 2. Pengawasan kurang }\end{array}$ & $\begin{array}{l}\text { Pantau } \\
\text { perkembangan } \\
\text { kelas }\end{array}$ \\
\hline 3 & $\mathrm{DH}$ & $\begin{array}{l}\text { 1. Suara lantang } \\
\text { 2. Interaksi bagus } \\
\text { 3. PPT menarik }\end{array}$ & $\begin{array}{l}\text { 1. Bicara cepat } \\
\text { 2. Bahasa kurang tepat }\end{array}$ & $\begin{array}{l}\text { Komunikasi/ } \\
\text { pengelolaan } \\
\text { kelas }\end{array}$ \\
\hline
\end{tabular}

Sumber: Pengolahan Data Penelitian 2017

Hasil observasi pada lembar refleksi pembelajaran ini dijadikan dasar untuk kegiatan refleksi yang dilaksanakan pada hari yang sama. Kegiatan refleksi pertama menjadi dasar untuk melaksanakan kegiatan "plan 2". Aspek yang perlu diperhatikan adalah pengelolaan kelas, penguasaan materi serta menambahkan sumber belajar dari artikel ilmiah.

\section{Analisis Pertemuan (Open Class) 2}

Pertemuan dilaksanakan pada hari Kamis, tanggal 4 Mei 2017. Capaian Kinerja dosen model adalah;

Tabel 5. Capaian Kinerja Pertemuan 2

\begin{tabular}{|c|l|c|l|}
\hline No & Kegiatan & Nilai & \multicolumn{1}{|c|}{ Keterangan } \\
\hline 1 & Pendahuluan & 80 & Lulus \\
\hline 2 & Kegiatan inti & 64 & Belum Lulus \\
\hline 3 & Penutup & 86,66 & Lulus \\
\hline
\end{tabular}

Sumber : Pengolahan Data Penelitian 2017

Tabel di atas memperlihatkan bahwa pada kegiatan pendahuluan dan kegiatan penutup, dosen model sudah tuntas dalam artian sudah melewati nilai ketuntasan minimal yaitu 70. Hanya saja, kinerja pada aspek kegiatan inti belum tuntas. Dalam pandangan dosen penilai, aspek yang masih perlu ditingkatkan adalah pemilihan model dan metode pembelajaran, peningkatan kualitas media presentasi, pengembangan dialog dan kolaborasi serta pemanfaatan referensi terbaru dari artikel yang sesuai dengan topik yang dipelajari.

Untuk mendapatkan bahan perbaikan lebih lanjut, berikut disajikan hasil lembar refleksi yang dicatat oleh para observer. 
Tabel 6. Refleksi Pembelajaran Pertemuan 2

\begin{tabular}{|c|c|c|c|c|}
\hline $\mathrm{No}$ & Observer & Tiga Kekuatan & Dua Kelemahan & Satu Solusi \\
\hline 1 & BLM & $\begin{array}{l}\text { 1. Sudah ada dialog } \\
\text { 2. Mahasiswa sudah } \\
\text { terlibat dalam } \\
\text { penggunaan media } \\
\text { 3. PPT lebih baik } \\
\end{array}$ & $\begin{array}{ll}\text { 1. } & \text { Berbicara } \\
\text { terlalu cepat } \\
\text { 2. Pemanfaatan } \\
\text { referensi masih } \\
\text { kurang } \\
\end{array}$ & $\begin{array}{l}\text { Penguasaan } \\
\text { model/metode } \\
\text { yang dipakai }\end{array}$ \\
\hline 2 & IM & $\begin{array}{l}\text { 1. } \text { Materi bagus } \\
\text { 2. Ada motivasi } \\
\text { 3. Siswa mulai aktif }\end{array}$ & 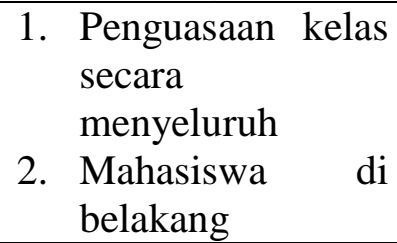 & $\begin{array}{l}\text { Pengkondisian } \\
\text { kelas }\end{array}$ \\
\hline 3 & $\mathrm{DH}$ & $\begin{array}{l}\text { 1. Ekspresif } \\
\text { 2. PPT sudah lebih } \\
\text { baik } \\
\text { 3. Penataan kelas di } \\
\text { awal bagus }\end{array}$ & $\begin{array}{l}\text { 1. Bicara terlalu } \\
\text { cepat } \\
\text { 2. Ide sulit dicerna }\end{array}$ & $\begin{array}{l}\text { Penguasaan } \\
\text { kelas }\end{array}$ \\
\hline
\end{tabular}

Sumber : Pengolahan Data Penelitian 2017

Berdasarkan hasil refleksi terlihat bahwa dosen model harus meningkatkan penguasaan model/metode yang digunakan serta meningkatkan penguasaan kelas secara menyeluruh.

\section{Analisis Pertemuan (Open Class) 3}

Pertemuan (open class) 3 dilaksananakan pada hari Rabu tanggal 10 Mei 2017 pada mata kuliah Geografi Sosial. Pada pembelajaran ini, satu observer tidak datang karena ada acara lain yang tidak bisa ditinggalkan.

Tabel 7. Capaian Kinerja Dosen Model Pertemuan 3

\begin{tabular}{|c|l|c|l|}
\hline No & \multicolumn{1}{|c|}{ Kegiatan } & Nilai & \multicolumn{1}{|c|}{ Keterangan } \\
\hline 1 & Pendahuluan & 93,33 & Lulus \\
\hline 2 & Kegiatan inti & 86,00 & Lulus \\
\hline 3 & Penutup & 93,33 & Lulus \\
\hline
\end{tabular}

Sumber : Pengolahan Data Penelitian 2017

Dari tabel di atas dapat diketahui bahwa dosen model telah menunjukkan peningkatan kinerja dalam pembelajaran baik pada kegiatan pendahuluan, kegiatan inti maupun kegiatan penutup. Pada ketiga aspek yang diamati, dosen model sudah tuntas. 
Berikut disajikan hasil catatan observasi dari lembar refleksi dari dua orang observer.

Tabel 8. Refleksi Pembelajaran Pertemuan (Open Class) 3

\begin{tabular}{|c|c|c|c|c|}
\hline $\mathrm{No}$ & Observer & Tiga Kekuatan & Dua Kelemahan & Satu Solusi \\
\hline 1 & BLM & $\begin{array}{l}\text { 1. Penyajian materi } \\
\text { bagus } \\
\text { 2. Komunikasi dan } \\
\text { dialog } \\
\text { 3. Ada humor untuk } \\
\text { mencairkan } \\
\text { suasana }\end{array}$ & $\begin{array}{l}\text { 1. Kadang bicara } \\
\text { masih cepat } \\
\text { 2. Pengawasan } \\
\text { mahasiswa di } \\
\text { bagian } \\
\text { belakang }\end{array}$ & $\begin{array}{l}\text { Kestabilan } \\
\text { kecepatan } \\
\text { berbicara }\end{array}$ \\
\hline 2 & IM & $\begin{array}{l}\text { 1. Penguasaan materi } \\
\text { bagus } \\
\text { 2. Pendekatan ke } \\
\text { mahasiswa bagus } \\
\text { 3. Penyajian materi } \\
\text { bagus }\end{array}$ & $\begin{array}{l}\text { 1. } \begin{array}{l}\text { Kecepatan } \\
\text { berbicara belum } \\
\text { stabil }\end{array} \\
\text { 2. } \begin{array}{l}\text { Kelas di belakang } \\
\text { kurang } \\
\text { diperhatikan }\end{array} \\
\end{array}$ & $\begin{array}{l}\text { Sesuaikan cara } \\
\text { bicara dengan } \\
\text { kondisi } \\
\text { mahasiswa/kelas }\end{array}$ \\
\hline 3 & $\mathrm{DH}$ & Tidak hadir & Tidak hadir & Tidak hadir \\
\hline
\end{tabular}

\section{Analisis Pembelajaran Pertemuan (Open Class) 4}

Kegiatan Open Class keempat dilaksanakan pada hari Jumat tanggal 12 Mei 2017. Pada pembelajaran ini dihadiri oleh dua orang observer. Berikut capaian kinerja dosen model;

Tabel 9. Capaian Kinerja Dosen Model Pertemuan (Open Class) 4

\begin{tabular}{|c|l|c|l|}
\hline No & Kegiatan & Nilai & \multicolumn{1}{|c|}{ Keterangan } \\
\hline 1 & Pendahuluan & 93,33 & Lulus \\
\hline 2 & Kegiatan inti & 92 & Lulus \\
\hline 3 & Penutup & 100 & Lulus \\
\hline
\end{tabular}

Sumber : Pengolahan Data Penelitian 2017

Berdasarkan tabel 9 terlihat bahwa dosen model telah berhasil mencapai level tuntas pada semua aspek yang diamati. Pada kegiatan penutup, dosen model telah mampu menunjukkan semua kegiatan yang digariskan yaitu melaksanakan konfirmasi, melaksanakan refleksi pembelajaran serta memberikan penugasan/penjelasan mengenai kegiatan selanjutnya.

Sedangkan hasil catatan observasi pembelajaran berdasarkan lembar refleksi pembelajaran dari observer pembelajaran adalah;

Tabel 10. Refleksi Pembelajaran Pertemuan (Open Class) 4

\begin{tabular}{|c|c|c|c|c|}
\hline No & Observer & Tiga Kekuatan & Dua Kelemahan & Satu Solusi \\
\hline 1 & BLM & 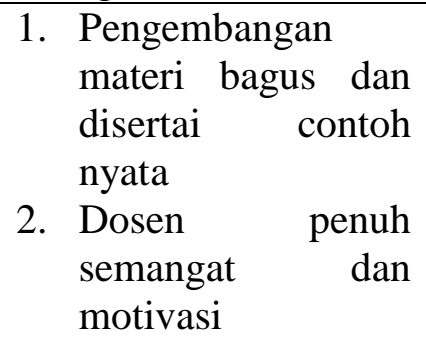 & $\begin{array}{l}\text { 1. Tulisan dosen } \\
\text { model kurang } \\
\text { jelas karena } \\
\text { menggunakan } \\
\text { spidol hijau } \\
\text { 2. Kadang } \\
\text { berbicara masih }\end{array}$ & $\begin{array}{l}\text { Latih kestabilan } \\
\text { berbicara saat } \\
\text { mengajar }\end{array}$ \\
\hline
\end{tabular}




\begin{tabular}{|c|c|c|c|c|}
\hline & & $\begin{array}{l}\text { 3. Mahasiswa terlibat } \\
\text { aktif dalam } \\
\text { pembelajaran }\end{array}$ & cepat & \\
\hline 2 & IM & $\begin{array}{l}\text { 1. Pendekatan ke } \\
\text { mahasiswa bagus } \\
\text { 2. Materi dikuasai } \\
\text { dengan baik } \\
\text { 3. Jelas poin-poin } \\
\text { materi }\end{array}$ & $\begin{array}{l}\text { 1. Perlu } \\
\text { memotivasi jika } \\
\text { ada mahasiswa } \\
\text { yang mulai } \\
\text { jenus } \\
\text { 2. Awasi } \\
\text { mahasiswa/ } \\
\text { Secara } \\
\text { menyeluruh } \\
\end{array}$ & $\begin{array}{l}\text { Perlu motivasi } \\
\text { berkelanjutan }\end{array}$ \\
\hline 3 & $\mathrm{DH}$ & \multicolumn{3}{|c|}{ Tidak hadir } \\
\hline
\end{tabular}

Adapun rekap perkembangan capaian kinerja dosen model dalam pembelajaran dari pertemuan 1 sampai pertemuan 4 dapat dilihat dalam tabel berikut ini;

Tabel 11. Perkembangan Nilai Pelaksanaan Pembelajaran PL-MGL

\begin{tabular}{|c|c|c|c|c|l|}
\hline Pert/Kegiatan & Pendahuluan & Inti & Penutup & Rata-rata & Keterangan \\
\hline 1 & 66,66 & 60,00 & 66,66 & 64,44 & Belum Lulus \\
\hline 2 & 80,00 & 64,00 & 86,66 & 76,88 & Lulus \\
\hline 3 & 93,33 & 86,00 & 93,33 & 90,88 & Lulus \\
\hline 4 & 93,33 & 92 & 100 & 95,11 & Lulus \\
\hline
\end{tabular}

Sumber: Pengolahan Data Penelitian 2017

Dari tabel 11 dapat diketahui bahwa dosen model mengalami peningkatan kinerja dalam pembelajaran pada aspek-aspek yang diamati secara meyakinkan. Tentunya peningkatan capaian kinerja tersebut dipengaruhi oleh berbagai faktor. Salah satunya adalah pola pembelajaran yang diterapkan. Dengan pola Kolaborasi Berbasis Lesson Study (KBLS), keempat mahasiswa PL- MGL bisa saling mengisi, saling menguatkan dan saling berkontribusi.

Dalam kegiatan "see", terbuka kesempatan bagi semua peserta baik mahasiswa maupun dosen untuk memberikan pandangan-pandangan dan masukan terhadap pembelajaran yang telah dilaksanakan. Dialog merupakan esensi dari kolaborasi. Untuk mengantisipasi adanya kesan menggurui dalam kegiatan "see", penulis menggunakan teknik "three way conference" dimana setiap observer merekam secara objektif perkembangan dosen model dimulai dari tiga hal yang menjadi kekuatan, dua hal yang perlu diperhatikan/diubah serta satu solusi terhadap masalah yang ditemukan. Dengan pola ini, akan meminimalisasi potensi terjadinya kesan "menghakimi" dosen model. Dengan berkembangnya dialog yang terbuka diantara peserta maka akan menjadi modal untuk perbaikan dan mendukung pencapaian mutu pembelajaran (Sato, 2012). Dengan dilaksanakannya PL-MGL dengan pola kolaborasi berbasis Lesson Study ini diharapkan dapat menanamkan pemahaman kepada peserta bahwa "effective teaching is a complex occupation requiring the development of knowledge and essential teaching skills as well as continous professional growth", artinya, pengajaran yang efektif adalah pekerjaan 
yang kompleks yang memerlukan pengembangan pengetahuan dan keterampilan mengajar yang penting serta pertumbuhan profesional berkelanjutan (Moore, 2005).

Walaupun kegiatan PL-MGL ini hanya berlangsung selama dua bulan dan praktik pembelajaran di kelas hanya satu bulan (empat kali pertemuan/open class), setidaknya dapat memberikan pelajaran (lesson learn) kepada peserta bahwa;

1. Setiap pendidik harus merenungkan pengajaran yang mereka lakukan. Pendidik serius mempertimbangkan apa yang akan diajarkan dan seberapa baik cara mengajarkan. Untuk mendapatkan rancangan terbaik, pendidik harus bekerja dalam suatu komunitas yang berisi orang-orang yang memiliki visi sebagai pembelajar (Danielson, 1996 dalam Moore, 2005). Kegiatan “Plan” akan menfasilitasi pendidik untuk mendiskusikan rencana pembelajaran terbaik.

2. Pendidik harus memahami bahwa setiap pribadi memiliki kekuatan dan juga kelemahan. Kekuatan harus dikembangkan dan kelemahan harus dikuatkan. Ada guru yang memiliki kemampuan lebih dalam perencanaan namun kurang baik dalam mengajar. Atau sebaliknya. Melalui dialog dan bekerja dalam sebuah komunitas belajar semua pendidik akan bertransformasi dan berkolaborasi sehingga kekuatan akan menjadi miliki bersama dan kelemahan akan dikurangi secara perlahan (Kemp, 1994). Kegiatan "Plan dan See" akan mewadahi pendidik untuk saling menguatkan dan saling mendukung.

Untuk mendapatkan pandangan peserta PL-MGL terhadap pelaksanaan teknik Kolaborasi Berbasis Lesson Study ini maka penulis melakukan wawancara dengan dengan mereka. Sebagai dosen model, Anisa Yudita mengatakan bahwa ; “.........PLMGL dengan pola ini cukup menantang. Bagi saya sangat bermanfaat. Walaupun kami harus mengalokasikan waktu lebih banyak dibanding teman-teman lain yang berbeda dosen pembimbing”. Lalu, observer yang bernama Belia Laksmi Masril menyatakan bahwa :"...Saya sebenarnya sudah lama mendengar lesson study. Tapi ikut terlibat secara langsung dalam kegiatan lesson study adalah pengalaman pertama saya. Saya senang bisa berbagi dengan kawan-kawan. Awalnya sempat terpikir bahwa teknik ini akan menyita waktu saya karena saya juga mengajar sambil kuliah. Tapi, setelah dijalani, saya mendapatkan manfaatnya". Hampir senada dengan observer pertama, Isni, M sebagai observer kedua mengemukakan bahwa :"....dosen memfasilitasi kami untuk selalu bersama. Itu bagus dan bagi saya sangat bermanfaat. Sehingga kami bisa saling mengisi. .....Walaupun waktu yang kami sediakan jauh lebih banyak tapi saya merasakan dampaknya terutama bagaimana membelajarkan peserta didik. Memang sebaiknya guru-guru selalu bersama mulai dari merencanakan, melaksanakan sampai dengan menilai pembelajaran". Walaupun sempat tidak hadir dalam kegiatan "open class", observer ketiga yang bernama Dewilna Helmi berpendapat bahwa : “ ...pada saat S1 saya sudah mengenal lesson study melalui pak dion. Beliau sudah sering mempraktikkannya dalam pembelajaran. Pengalaman PL-MGL ini cukup berharga karena saya terlatih untuk menjadi calon dosen/pendidik". Dari semua pendapat di atas, baik yang dikemukakan oleh dosen model maupun observer terlihat bahwa semua peserta PL-MGL merasakan manfaat dari pelaksanaan PL-MGL dengan pola Kolaborasi berbasis Lesson Study. Mereka dapat bekerja dalam suatu komunitas bersama yang sama-sama memiliki kepentingan untuk mengembangkan kompetensi masing-masing sebagai calon pendidik profesional. 
Setelah kegiatan PL-MGL selesai, penulis melakukan wawancara dengan Ketua Program Studi Magister Pendidikan Geografi, Dr. Dedi Hermon, S. Pd., M. P. Menurut nya "...PL-MGL dengan pola kolaborasi berbasis Lesson Study sangat bermanfaat dan sangat membantu mahasiswa untuk saling menguatkan dan berkontribusi. Ke depan pola ini akan dijadikan sebagai salah satu model pelaksanaan PL-MGL di Program Studi Magister Pendidikan Geografi untuk angkatan berikutnya...”.

\section{KESIMPULAN DAN SARAN}

Dari hasil yang telah dipaparkan terlihat bahwa pelaksanaan PL-MGL dengan menerapkan prinsip-prinsip kolaborasi berbasis Lesson Study mampu meningkatkan kemampuan calon pendidik/dosen baik dalam aspek perencanaan, pelaksanaan maupun penilaian pembelajaran. Tidak hanya itu, PL-MGL dengan pola kolaborasi berbasis Lesson Study juga dapat mewujudkan terciptanya komunitas belajar dalam upaya mengembangkan kompetensi calon pendidik profesional secara berkelanjutan. Semoga ide dan hasil penelitian sederhana ini bisa menjadi alternatif bagi pembaca untuk melaksanakan program pengembangan kompetensi bagi calon pendidik baik guru maupun dosen di lingkungan masing-masing.

\section{DAFTAR PUSTAKA}

Buku Pedoman Sertifikasi Pendidik untuk Dosen (Serdos) Terintegrasi. (2015). Direktorat Jenderal Pendidikan Tinggi. Kementerian Pendidikan dan Kebudayaan Republik Indonesia

Gokhale, A, Anuradha. 1995. Collaborative Learning Enhances Critical Thinking. Volume 7, Nomor 1, Fall tahun 1995. Journal of Technology Education

Johnson W, D., Johnson T. Roger \& Holubec. 1986. Colaborative Learning (Strategi Pembelajaran untuk Sukses Bersama). Penerbit Nusa Media. Bandung

Kemp, J. E., Morison, G. R \& Ross, S. M. 1994. Designing Effective Instruction. New York:Macmillan College Publishing Company

Laal, Marjan. 2013. Positive Interdepence in Collaborative Learning. Procedia - Social and Behavioral Sciences 93 (2013) p. 1433-1437. Elsevier. www.sciencedirect.com

Laal, Marjan, Geranpaye, Loabat \& Daemi, Mahrokh. 2013. Individual Accountability in Collaborative Learning. Procedia - Social and Behavioral Science 93 (2013) p. 286-289. Elsevier. www.sciencedirect.com

Lewis, Cathrine. 2002. Does Lesson Study have the future in United State?. Artikel Online. Nagoya Journal of Education and Human Development. Januari 2002. Nomor 1 Halaman 1-23. Web. clewis@ mills.edu diakses 20 Januari 2016

Moore, D, Kenneth. 2005. Effective Instructional Strategies From Theory to Practice. Sage Publication. California - London -New Delhi 
Sato, Manabu. 2012. Mereformasi Sekolah. Jakarta. PELITA/JICA

Sato, Masaaki. 2012. Dialog dan Kolaborasi di Sekolah Menengah Pertama. Praktek “Learning Community”. Jakarta. PELITA/JICA

Setyosari, Punaji. 2010. Metode Penelitian Pendidikan dan Pengembangan. Prenada Media Group. Jakarta

Undang-undang nomor 14 tahun 2005 tentang Guru dan Dosen 